\title{
CREATING ATMOSPHERIC COHERENCE THROUGH COMMEMORATIVE RITUALS, SINGING PARTISAN SONGS, AND REHEARSED AFFECT
}

\author{
MOJCA KOVAČIČ \\ ZRC SAZU Institute of Ethnomusicology, Ljubljana
}

\begin{abstract}
This article presents aspects of affective atmospheres in the context of commemorating the events of the Second World War in post-socialist Slovenia. Particular emphasis is placed on the role of partisan songs in establishing relations between the past and the present, discussed with specific reference to commemorative events and the experiences of singers in a rural choir. Individual narratives revealed the internal dynamics of each singer's experience while singing partisan songs, as well as the role that collective memory, the past, history, politics, and personal narratives play in that experience. The singers' experiences also provide the basis for questioning the concepts of coherence within the theory of affective atmospheres.
\end{abstract}

Keywords: commemoration, rituality, affective atmospheres, rehearsed affect, partisan songs

\section{INTRODUCTION}

Years ago, I joined a local amateur mixed choir and started participating in various concert events that the choir attended every year. ${ }^{1}$ In addition to participating in regional choir festivals held under the auspices of the governmental institution for amateur culture and art, staging an independent annual concert, and participating in local school events, the

${ }^{1}$ This article is part of the project Music and Politics in the Post-Yugoslav Space: Toward a New Paradigm of Politics of Music at the Turn of the Century (J6-9365) and the research program Research on Slovenian Folk Culture in Folklore Studies and Ethnology (P6-0111), which are financially supported by the Slovenian Research Agency (ARRS) 
choir also performs at commemorations that frequently take place in the vicinity. On such occasions, they only sing partisan songs. The partisan connotation is also evident in the name of the choir, Zora Janče, which it borrowed from the partisan name of the conductor's mother. The commemorations where the choir regularly sings mark events related to the National Liberation Movement (NLM) and partisan resistance, ${ }^{2}$ and the area where a commemoration takes place is also seen as a "partisan zone" in the local conception of space. ${ }^{3}$ Moreover, I have noticed that some local residents regard the choir as a "partisan choir". Later, I realised that the choir also excels in outstanding heartfelt interpretations of partisan songs at choir festivals, which is why partisan songs are often included in their repertoire, even when the events do not contextually relate to historical meanings carried by the partisan song (e.g. at choir festivals, and at the annual choir performance).

Having participated in several commemorations, I gained insight into the content of these events and their programme conception, which I had not otherwise visited beforehand. The content is tied to past and current political events, and they reflect certain ideological views of the past and have the potential to create a contemporary political reality, which causes a stir in post-independence Slovenia, polarising Slovenian public opinion. I was convinced that participation in such events also reflects the choir's adherence to the ideas and attitudes presented there. Only after having participated in the choir for about a year, did I first notice fellow choir singers complaining during a commemoration event about the choir participating in such events. On other occasions, I observed the conductor complaining that some members did not participate in a commemorative event, stressing the obligation of individuals to the community that the choir represents. The conductor further justified attendance by noting that such events are the only occasions when the choir receives payment. However, participation was never a subject of discussion among the choir members at rehearsals; so, I started to wonder what makes singing at a commemoration problematic.

Since singing partisan songs at commemorations was a powerful emotional and affective experience for me as a choir member, and I knew the context of the choir's performances and contemporary commemorative practices in Slovenia, I was attracted to conduct a more in-depth study. Within the context of the study, I am particularly interested in the affective capacity of the commemoration and of collective singing to establish relations between the present and the past. This starting point led me to consider the political character of music within the context of commemorations connected with the $\mathrm{NLM}^{4}$ and ways of establishing affective atmospheres through ritualization, behaviour, and visual

2 The partisan movement (formally the National Liberation Army and Partisan Detachments of Slovenia) was part of the European anti-Nazi resistance during the Second World War.

${ }^{3}$ I take the expression from the popular designation of the territory, which is common to some areas in the vicinity of the Municipality of Ljubljana. A distinction is made between whether a partisan movement (i.e. partisan zone) or a home defence movement (i.e. home defence zone) was present in a given area during the Second World War.

${ }^{4}$ Commemorations "often mobilise national history to serve contemporary political ends through the people and events they memorialize" (Sumartojo 2015: 7). After 2000, researchers have observed an 
and sound mediations. The fundamental questions I ask myself are, therefore: how do commemorations establish links with the past, what tools do they use, and what sort of a tool is music in this case, with specific focus on the affective potential of partisan songs?

In this article, I start by situating an event that takes place in Janče near Ljubljana within a broader discourse about commemorations in the post-socialist context. Through my attendance at the event, I analyse the tools of mediation between the past and the present. I proceed by introducing the role of music as a connecting force, both among the participants at the event and in linking the past to the present and the personal and collective memories to the immediacy of the event. The article continues with a section on the re-actualisation of partisan songs in the context of choir singing after 1991, and how it influenced the understanding of their present-day political nature. This is the basis for understanding the singers' personal testimonies about their experiences during commemorations and singing. "[T]he view from without and the view from within the music itself" (Atanasovski 2015: 72) have been included in terms of methodology. ${ }^{5}$ At the same time, this provides insight into the differences in the performing practices of two diverse collectives - activist choirs and "traditional" choirs.

Verbalizing emotional and affective experiences poses a methodological challenge, because "people are rarely able to articulate sensory responses or they usually describe them with a time lag and by referring to feelings, moods, or emotions" (Hofman et al. 2020: 60). ${ }^{6}$ In my research, I wanted as many members of the choir as possible to describe their affective and emotional experiences of singing and attending the event. To that end, on the day of the event, I distributed recording bracelets, old cell phones, and sound recorders to eleven singers and asked them to record their experiences at the event itself or immediately after it.? It seemed to me that in this way I could come closer to the immediate affects of the singers, while simultaneously preventing their method of recording affecting the structural order of their answers, as is usually the case with an interview. ${ }^{8}$ Thus, individual

increase in commemorations, and with it an increase in interest in issues related to the past and to history, as well as in public expression on these issues (Winter 2001; Doss 2012).

${ }^{5}$ Atanasovski suggests applying these two views when conducting music and sound studies. According to the first view, sound events should be understood as a vibrational body affecting other bodies, and according to the second, he proposes that the researcher should use an emic approach and be physically present at the event, in order to understand it as a network of meanings, since "different layers of meaning can trigger different embodied memories through participatory practices and musical artefacts” (2015: 72).

${ }^{6}$ Because affect as a physical response is measured in neuroscience and music psychology using the methodology of experimental music emotion recognition (MER) and the measurements are made in the laboratory at this time, affect is often excluded from the context.

7I wrote more about this methodology in a blog on the project website "Music, Affect, Politics" (Kovačič 2020).

${ }^{8}$ I also wanted to avoid a structured interview because my research questions were not thematic, but I wanted to have a free-form conversation that could be thematically connected to anything. However, this approach did not quite work out. Several singers anxiously asked me several times what I actually wanted from them. So I ended up giving them slips of paper with brief clues about what they should talk about - the feelings they experienced throughout the event and while singing, how they experienced the audience... Despite the hints, in most cases their narratives turned out to be quite unstructured and free. 
narratives revealed the internal dynamics of individual choir singers' experiences of singing and how their stories resonate with the collective memory, the past, history, politics, and personal experiences. These narratives are also the basis for examining the concept of coherence within the context of the theory of affective atmospheres.

\section{FORMATION OF COLLECTIVE MEMORY THROUGH COMMEMORATIVE RITUALS AND AFFECTIVITY}

Commemoration is a ritual act that institutionalises a collective memory or a representation of the past that builds a shared identity or consciousness of collective belonging. It is a practice that establishes present-day relationships with the past. Indeed, commemoration represents the past "that is being remembered, performed, and retold in the present, thus enabling both the real and fictional memories to become 'real' in their narration" (Schultz 2016: 265).

Commemoration is also a ritual actualization of memory that establishes or maintains different interpretations of history. ${ }^{9}$ It is an institution that controls both collective memory and its "counterpart, non-memory or oblivion" (Kos 2019: 234). To maintain desired interpretations and narratives about the past and establish shared feelings in the present, it is necessary to direct these memories. Memories, after all, "only exist if we shape them into words, images, sounds, and communicate them within the social environment" (Hofman 2020b: 179). Therefore, the "orchestration" of shared memories is most often produced through the bodily experience of sound or images, and thus memories are "sedimented or amassed in the body" (Connerton 1989: 102). Visual and aural stimuli, supported by ritual behaviour, arouse emotional and affective states in participants and in this way help to make the past physically tangible. As Fuchs claims, "The more the different senses participate in the ritual [...], the more lasting its sedimentation in the individual body memory and the more intense the shared experience of its reactualization" (Fuchs 2017: 344).

Another important aspect of ritualization and embodiment of the commemoration is its repetition. By being repeated annually or several times, ritual events become more predictable, as the participants are familiar with the rules of conduct in advance. Such "mimetic relations between former, present, and future ritual acts" also reinforce "collective body memory" (ibid.: 344).

\footnotetext{
${ }^{9}$ Luthar offers a more detailed explanation of how history is interpreted in post-socialist Slovenia. The author distinguishes among three types of interpretations according to which collective memories and the associated memory landscapes are mobilised: "the authoritarian type, defined by a desire for direct colonization of the interpretation of the past related to the Second World War; the conciliatory type that tries to achieve 'reconciliation'; the conflicting type that clashes with the iconography of an existing partisan monument as an alternative interpretation" (Luthar 2013: 882).
} 
To understand how the experience of words, images, and sounds interactively affects space and "bodies" present at the commemoration, we can also turn to the theory of affective atmospheres. ${ }^{10}$ Friedlind Riedel, who also links the concept of atmosphere to the realm of music and sound, refers to the German phenomenologist Hermann Schmitz. Already in the 1960s, the latter considered affective atmospheres (in German, "Stimmungen") as a "surfaceless space" that is related to the so-called felt bodies (2019a: 4). Thus, Riedel also defines such feelings as "spatially poured out atmospheres" (ibid.: 20), something that is in the air and exists outside bodies but not without them (cf. similarly Anderson 2009). This concept challenges the perception of feelings "as being the mere mental states of a cognizant subject and instead construes feelings as collectively embodied, spatially extended, material, and culturally inflected" (ibid.: 4). The awareness that emotions and affects are action-oriented (Smith et al. 2018: 1) also leads protagonists of commemorative events to carefully select visual and auditory stimuli that serve to mobilise the appropriate affective and emotional experiences and create desired affective atmospheres.

With their evocation of the past, commemorations are also powerful co-creators of our experience of the present and future. In Dominic Bryan's words, they are "a way of capturing the sacrifices of the past" in order to use them to legitimise "the political present and the imagined political future" (2016: 24). Therefore, Bryan emphasises that modern structures of commemoration can be better understood by examining "the relationship between identity and contemporary politics, than by examining the event being remembered" (ibid.). Very often, a link between national identity and collective memory is (re)established through commemoration of a specific event. Thus, remembering the content of a particular event (e.g., the 1941 war conflicts) is re-contextualised from local to national (e.g., the struggle for Slovenia) or transnational meanings (e.g., the struggle against fascism), resulting in the reconfiguration of "the connection between national identity and collective memory" (Saito 2010: 629). Commemorations are therefore an important tool or weapon to legitimise contemporary politics; political parties involved also recognise this, either in the organisation of the commemorations or through the presence and speeches of party representatives at the event. ${ }^{11}$ I present an example of a specific commemorative event, pointing to the tools that establish affective relations between the present reality, identity, collective memories, and the past.

${ }^{10}$ Both in the context of discourse and in the literature where the theory of atmosphere is not foregrounded, atmosphere is often considered to be something we feel, something that is in the air, something that permeates the sense of the group that we feel, for example, when we enter the room (Brennan 2004: 1) or that we can illustrate with examples, such as collective mourning at funerals or enthusiasm at a football match. Thus, atmosphere is mostly used as a term characterising a collective mood or ambience that is important, for example, as a tool to achieve certain goals, such as generating consumer behaviour in a marketing environment where sounds and smells play an important role as stimuli (Hedström et al. 2015; Chebat and Michon 2003).

${ }^{11}$ Luthar notes that commemorations in the post-socialist context in Slovenia have three common points, namely that they focus on the national context, ignore the chronology of events, and have a moralising character (Luthar 2017: 9). 
Janče is an area on the outskirts of Ljubljana. It is on a hill, on the top of which is a mountain hut with a large meadow and a parking lot, which allows for the organisation of various events.12 Once a year, the Union of the Associations for the Values of the National Liberation Movement of Slovenia (ZZB NOB Slovenia) organises a commemorative event to commemorate the clashes of May 18-22, 1941, when the partisans fought against 2,000 German soldiers and policemen. Seventy Germans and 11 NLM fighters were killed in this conflict, among whom Jože Kovačič was later declared a national hero. Although the commemoration celebrates a specific historical event, it also places it in the contemporary context that correlates with the collective memory of the Second World War, the NLM, partisans, anti-fascism, communism, socialism, Tito, Yugoslavia, Slovenian independence, and other types of state-building discourse. This is contrasted with the construct of or correspondence with collective memory, which correlates (often also at the level of commemoration) with memories of the war that pitted brother against brother and of resistance, anti-communism, post-war massacres, gravesites, the current right-wing interpretations of the Second World War, and the state-building discourse of independence. ${ }^{13}$

At the event, these connections are also made concrete through behavioural and physical perspectives of the commemorative ritual, such as the laying of wreaths and marching by a makeshift partisan force, the hanging of flags and standards, and the awarding of medals. Speeches referring to historical events, the conflict in Janče, the life story of the hero Jože Kovačič, and elements of the Yugoslav socialist past and the current political situation (i.e., the political struggle for the memory of the events during and after the Second World War) additionally reinforce the meaning. Speeches by the organisers and invited honorary speakers also express inclination toward or opposition to certain political parties, ideologies, or views expressed in the public media discourse. It is of particular importance that speeches are given by prominent public figures, such as representatives of the association, the former president of the country, the mayors of two cities whose borders meet at the place of commemoration. It is thus important "who attends the commemoration" and "how they behave", which is reflected both in the greetings of the speakers, emphasising the presence of prominent public figures in the audience, and in

\footnotetext{
${ }^{12}$ At the commemorative event, mountain hut managers offer catering services (drinks and food), where local residents also sell their products. The culinary offer of the hut includes sugar sachets with a picture of a Yugoslavian flag, which has already triggered criticism from two politically right-wing media companies (Nova TV and Reporter). The hut also has a memorial room dedicated to the 2 nd partisan detachment group.

${ }^{13}$ By this I mean the so-called commemorations of the victims of the war and the revolution or home guard celebrations, which use, for example, the mass ceremony, the blessing, the home guard anthem, the home guard uniform, and the flag as a means of establishing rituals and an affective atmosphere. Further reflections on the political struggle to redefine the past after Slovenia's independence and on historical revisionism through the prism of home guard monuments have been documented by Oto and Breda Luthar in the article "Colonisation of Memory: Politics and Textuality of Home Guard Monuments after 1991" (2003: 647-662). Cf. also Luthar, Oto and Heidemarie Uhl, "The Memory of Guilt Revisited: The Slovenian PostSocialist Remembrance Landscape in Transition” (2019).
} 
the subsequent media coverage of the event, which mentions them. ${ }^{14}$ Moreover, the commemoration is "a platform for memory transfer [...] to subsequent generations" (Schoop 2020: 2), as we can observe young people and children among the spectators and actors at the event. They come either from the surrounding schools or from music schools, and some of their performances are woven into the political historicisation of the commemoration in terms of content or through the music, while others have performances that are unrelated to its context. ${ }^{15}$

The scenery is prepared by the organisers of the celebration (e.g., standards, flags, placards, red carnations, partisan uniforms, etc.), as well as by the visitors themselves. Thus, we are also able to see how audience members interact with the past and how they articulate it in the present. However, on the one hand, their behaviour is ritualistic and emotionally normative (we can observe the same patterns of behaviour at similar events), while on the other hand, this attitude is non-normative outside the commemorative context; so, we can say that commemorations offer people a kind of emotional escape. This means that people behave differently in this space than they do otherwise and that this offers them emotional solace. Thus, some already prepare for the event in their own home environment, dressing up in red clothes and rummaging for classic green side caps (titovke), badges, decorations, and other military clothing from the Second World War, while others bring the Yugoslav flag; and this year an increase in the wearing of tourist products related to the Yugoslav heritage has been observed (T-shirts with Tito's image, earrings with a five-pointed star). Besides the mentioned visual elements, there is also a certain predictable ritual movement and attitude connected to music - singing along with the choir during certain songs, standing up collectively when certain songs are sung, verbal expression of approval, cheering, and applause.

\section{AFFECTIVE ATMOSPHERE AND MUSIC AT THE COMMEMORATION}

Many studies examining "sound as an affective binding force" (Garcia 2020: 22) emphasise that sound has the power to unite individuals into synchronous affective collective bodies, wherein lies its potential for political collectivization (cf. Hofman 2015c; Garcia 2020; Thompson and Biddle 2013). They see in affect "emancipatory potentials in alternative modes of political and cultural production" (Hofman 2015c: 49). ${ }^{16}$ Accordingly, sound is

\footnotetext{
${ }^{14}$ For example, after a sensational concert performance by the Pinko Tomazič Partisan Choir, held on the Day of the Uprising in the largest Slovenian hall in Stožice, the following appeared in the media: "For the occasion, Mrs Bratušek chose a shiny red dress, which she combined with matching nail polish, Janković put on a red T-shirt, Barbara Miklič Turk wrapped a red silk scarf around herself, and her husband, together with Kučan and Stanovnik, opted for a red tie. Borut Pahor attended the event without a tie" (Hacler 2013).

${ }^{15}$ I observed that some parents problematized their children's performance at a politically oriented event. Maybe that's why teachers sometimes opt for content-neutral performances.

${ }^{16}$ Different theorizations of affect create considerable confusion in the use of terms and concepts (cf. e.9., Massumi 2002; Mazzarella 2009; Ahmed 2004; Brennan 2004). In this article, I understand affect
} 
not just a medium of tonal, rhythmic, harmonic, and other vibrations. Riedel, who bases the concept of affective atmospheres within the context of music and sound, emphasises that the atmosphere is not merely a consequence of musical processes, but rather their essential component. In fact, music as an affective force not only directly relates to an individual, his ears, or his body, but also to the environment and transformational processes of spaces, collectivities, and situations. In itself, music unites the musical-aesthetic potentials and the potentials of political character, memories, nostalgia, personal and collective narratives, the past, and modernity that are "constructing, combining, manipulating or curbing atmospheric relations" (Riedel 2019a: 6).

Music, as an indispensable element of commemorations, sometimes has the role of softening the atmosphere (also performatively-emotionally) after the speeches, whose content is history- and politics-heavy; sometimes it adds meaning to the spoken word, thus supporting or reinforcing the existing atmosphere. For example, at the specific event in question, ${ }^{17}$ the anthem was first performed in a very emotional solo interpretation, then two female singers performed famous partisan songs harmonizing in two parts with accordion accompaniment, and a popular music artist delivered a lip sync performance of a patriotic song. The audience was familiar with some of the music, which gave them the opportunity to actively participate by singing, thus increasing the affective potential or contributing to the event's affective atmosphere. At the end of the event, the local choir performed three partisan songs, to which I pay special attention because the singers of these songs participated in the empirical part of the research. The experiential aspect of the partisan songs is a complex paradigm for understanding the connections of the personal, the collective, memory, culture, and history with the emotional-affective aspects of sound (cf. also Hofman 2015a).

If, on the one hand, the representative character of partisan songs is manifest in their textual elements (e.g. descriptions of the struggle against the occupiers and injustices, praise of the fallen partisans) and musical structural elements (e.g. dotted rhythm, extreme dynamic ratios, simple harmonic scales), ${ }^{18}$ on the other hand, it is also necessary

as intensity that objects, signs, and symbols induce in an individual's bodily and emotional experience, while these bodily and emotional intensities (associated with past experiences and memories) pass from an individual to the environment, attaching to affects, passing between bodies, and creating a collective affective atmosphere.

${ }_{17}$ Excerpts from the commemoration with these musical performances are available on the YouTube channel Music, affect, politics (https://www.youtube.com/watch?v=EPaDXHrhgWA).

${ }^{18}$ However, a look at the musical structures of the partisan songs reveals some typical features, which Franc Križnar provides on the basis of an analysis of 300 musical works created by 70 Slovene composers during the NLM period. Especially in the first period (1941-1943), these songs were often adaptations of folk songs and songs that became popular, or songs composed "in the spirit of folk melodicism" (Križnar 2014: 389), with simple melodies, harmonies, and common tempos that were not vocally complex, which certainly contributed to their general popularity. If the folk song was performed with flat dynamics, the dynamics of the partisan song fluctuate "between its two extremes", i.e. piano and forte. The predominantly lyrical songs were accompanied by works with epic, martial, hymnal, and satirical lyrics. As a specific characteristic of the partisan songs written during the NLM in Slovenia, he mentions "the specific rhythm of certain melodies and tunes" (ibid.: 391), which refers to marching songs. 
to understand their non-representative aspect, which shows their spatial and temporal relations through the emotional and affective experience of the sound. In other words, the partisan song can be understood as the sound potential that establishes an affective relationship with the environment, the affective atmosphere, the performers, the listeners, their memories of the past, and the experience of the present through the consciously interpreted and composed musical work (with textual, rhythmic, melodic, harmonic elements, volume, and interpretation). Through its spatial and temporal perspective, a partisan song can be considered a historical sensorium ${ }^{19}$ that carries a "multi-layered web of meaning" (Atanasovski 2015: 72) in the sound experience of the individual. To understand the complexity of these meanings, in what follows, I outline the understanding and actualization of partisan songs in the Slovenian contexts after 1991, as this provides a basis for understanding some of the experiences of the singers of the Zora Janče Choir presented below.

\section{THE PARTISAN SONG AND ITS SOCIO-POLITICAL RE-ACTUALISATIONS}

In the post-independence period, due to Slovenia's stronger national identification with the partisan movement (compared with other post-Yugoslav countries), the partisan song was also re-actualized in the Slovenian context in discourses of patriotism, freedom, national resistance, and the preservation of Slovenian cultural and linguistic identity (Hofman 2015a: 48-56): "The partisan musical heritage was not discredited, discriminated, or neglected as in other parts of Yugoslavia, but transformed, nationalised, and incorporated into the national musical corpus" (ibid.: 56). ${ }^{20}$ Hofman finds that it was not exceedingly equated with the communist past, which, during Slovenia's independence, symbolically represented an aggressor (ibid.: 49); but in the context of the commemoration and partisan song today, we can still speak about these symbolic links. ${ }^{21}$

In the last decade, the actualization of revolutionary and partisan songs has been more present in the Slovenian, ex-Yugoslav, and wider international arenas in the context of the struggle against nationalism, neoliberalism, social inequalities, and neo-fascism (Hofman and Pogačar 2017; Petrović 2016; Hofman 2015b; Spinetti et al. 2020). More specifically,

\footnotetext{
${ }^{19}$ Defined as a "matrix of sensibilities and perceptive possibilities that congregate at a particular moment” (Highmore 2018: 282).

20 This is illustrated by a picturesque example of redaction of the text of the partisan song entitled Freedom Song (Pesem o svobodi). The choir discussed in this article changed the phrase "new Yugoslavia" to "our Slovenia" (Hofman 2015a: 56) in its final version.

${ }^{21}$ This is also shown by the experience of musical recordings of performances by choirs such as Trieste's Pinko Tomažič Partisan Choir or Kombinat Female Choir, as described by listeners in the YouTube comments section. The experience of music is not always socio-politically themed, so many comments are on the aesthetic component of the performances. In many cases, we come across positive comments, and sometimes the quality of the singing is criticized.
} 
the partisan song, sung either by an activist choir or by demonstrators at protests, is used to "(re)articulate the values or set the parameters for potential alternatives to the present conditions" (Hofman and Pogačar 2017: 22) and usually represents a struggle against current social injustices, inequalities, and certain political ideologies. ${ }^{22}$ On the other hand, singing partisan songs is also understood as a cultural and symbolic actualization of left-wing party politics and as such finds itself in the field of tension of current political conflicts. ${ }^{23}$

The contemporary actualization of the partisan struggle through song is represented by the self-organized activist choir Kombinat, one of the most widely recognized choirs that re-actualizes songs from the Second World War today in Slovenia. The choir emphasises its democratic internal organization, with non-hierarchical structure and decision-making. It wishes to distance itself from political party affiliation, but it does not always succeed in doing so in the eyes of the public. Ana Hofman describes the ways in which the choir seeks to actualize historical manifestations and meanings that singing these songs had in their original context, the time of the national liberation struggle. For example, they perform as guerrilla activists and renounce the "regime" repertoire that emerged after the Second World War ${ }^{24}$ in order to distance themselves "from the official appropriations of the partisan resistance that took place during socialism" (Hofman 2015a: 132) and from current political appropriations as well. Such performances are considered a form of "authentic" representation of history in contemporary society. Hofman demonstrates the ineffectiveness of these conceptual approaches with examples of established silent hierarchies (including those in the repertoire policy), while describing stage concerts, commemorative events, and similar performances as being unable to distance themselves "from the formalisation and appropriation" of partisan song "by socialist cultural politics" (ibid.: 88). The reluctance to associate the idea "with Yugoslav socialism and nostalgia and to distance itself from left-centre-wing parties that appropriate the repertoire for political purposes" (ibid.: 140) is also often at odds with the discourses in which some media place the choir or how listeners experience it. ${ }^{25}$

The Zora Janče Mixed Choir was formed in 2004. The conductor had previously led several choirs, and many members followed her into this choir when she moved to Janče

\footnotetext{
22 In her article "We are the Partisans of Our Time: Antifascism and Post-Yugoslav Singing Memory Activism" (2020a), Hofman describes how post-Yugoslav activist choirs brought to life the values and meanings of the historical legacy of Yugoslav antifascism.

${ }^{23}$ As an example, one can read the article entitled "Partisan Songs Sung by the 'Red' Slovenian Politicians”, published on MMC's national media portal (Hacler 2013).

24 The partisan song originated both during the Second World War and afterwards, when it reflected the creativity of the regime at the time.

${ }^{25}$ On one forum, for example, someone calls them "the choir of transitional leftists composed of nationally minded/seduced communists" (https://slo-tech.com/forum/t762247/p6769714, accessed 20 December 2020). The global or post-Yugoslav audience that comments on the performances posted on the YouTube channel also comments on historical and political events, e.g. https://www.youtube.com/ watch?v=bF8To8oj9N4, https://www.youtube.com/watch?v=Prw-Whnm5yA, https://www.youtube.com/wa tch?v=OJkFdpVHtb4\&list=PLHFzXul8z1AVS6nDfM43d2pJifgRDaCvF\&index=21.
} 
and founded a choir there. This is reflected in the fact that many members come from more remote and quite diverse places around Ljubljana. The age structure is varied; there are both twenty and eighty-year-olds in the choir, and there are more retired members than those active. The hierarchical structure of the choir is clear and similar to most other choirs. The choir is organized as an association, within which roles such as treasurer, secretary, president, and vice-president are determined. The conductor, as the artistic director, also relies on these people the most when developing the choir's repertoire or attending to organizational matters. The conductor consults with all the members of the choir at singing rehearsals on the decisions taken. The issues most discussed are repertoire and participation in certain performances. As I have already mentioned, however, participation in the local commemoration is not discussed, and one can surmise that broaching this subject would bring to light singers' diverse individual feelings and desires regarding it.

Singing partisan songs, such as those sung by the Zora Janče Choir, is not the result of intentional collective political activism. However, some people experience it physically and emotionally through some of the historical discourses presented above and "sticky associations" 26 with rebellion, the fighting spirit, passion, pain, and sadness, as one of the singers put it:

Partisan songs are steeped in fighting spirit, passion, sadness, and sometimes pain. And all the things I've mentioned so far, I feel when I sing these songs, too. Either through the lyrics or through the music itself. Let's just say, when I'm performing, I feel those things physically as well. I would say with a tingling stomach, my hair stands up, but most of all there is such a fervour in me that it actually even corrects my posture, my shoulders lift, my head lifts, I sing loudly, at the top of my lungs, if the nature of the song is like that... or I sing songs that are imbued with a certain sadness, pain, with extreme subtlety. (M. V., 1 June 2019)27

The singer expresses a similar understanding of the partisan song, as represented by activist choirs in contemporary re-actualizations of NLM music, in which they also emphasise mutual solidarity as a value strongly repressed from everyday life:

Personally, I particularly like the idea of partisan songs. Why? Because it seems to me that these songs should be preserved, especially because the lyrics, also the music, of these songs represent, at least to me, some values that have been forgotten today, especially camaraderie. I grew up in a time when comradeship in the truest sense of the word still meant something. (M. V., 1 June 2019)

The Zora Janče Choir has included partisan songs in its repertoire since its founding in 2008. Singing partisan songs is a part of the chorus collective, accepted uncondition-

${ }^{26}$ Sara Ahmed emphasises that affects move through "sticky associations" between "signs, figures, objects" and sounds. They are also accompanied by complex meanings or experiences that are "bound up with the 'absent presence' of historicity" (2004: 20).

${ }^{27}$ Since I promised the singers to preserve their anonymity when presenting their answers, I give only their initials and the date of the recording. 
ally by anyone who joins. The choir considers partisan songs part of the repertoire of its universal musical expression. ${ }^{28}$ Partisan songs are presented on "traditional" concert stages as well as at commemorations. The conductor determines where, when, and what the choir will sing. Some singers regard participation in the commemoration in Janče as an actualization of history, closely intertwined with the political instrumentalization of the past; this is reflected in both appreciative and disapproving attitudes toward participation in and experience of the event. The following narratives suggest such ambivalences or "experiential messiness" (Ahmed 2010: 30; cf. examples in Hofman 2015a: 111) related to political understandings of history, past and present, or personal and familial narratives and memories:

But I'm here for the singing, not the partisans. Which seems a little funny to me, I mean, of course you have to respect that fight and what happened. Just, it's not like they had a choice, and now they're praising it and making this struggle of people into some politics and flags and speeches that last three hours: that seems a little pathetic to me, I don't know. (A. B., 1 June 2019)

I am always in a dilemma when we sing in Janče. I used to feel like I was betraying my family because my parents were so anti-partisan - interesting, considering that my ancestors were also partisans and victims of Nazism - but now I see that it actually bothers me, that I don't like this agitation and fanaticism, and that I am betraying myself for the benefit of the collective. (N. H., 1 June 2019)

Indeed, singing in Janče is, on the one hand, an honour and an awareness that some important historical moments have taken place here, but at the same time it is always accompanied by a certain weight of still on-going discord. So, despite the beautiful nature, although I respect the National Liberation War a lot and I like the idea of partisan songs because they carry a really strong charge in terms of resistance and visions for a better tomorrow, however, too often at such events we remain somewhere in the past, in disputes. (T. P., 1 June 2019)

The singers never expressed these kinds of feelings at singing rehearsals; I observed them only in one-on-one conversations with some singers at the commemorations, and I noticed that some "talked their way out of" performing at a commemoration with a made-up excuse. The fact that singers do not publicly comment on participation in performances suggests that they accept subordination in terms of belonging to the collective as a structure that operates in accordance with hierarchical principles. The participation of the local choir in Janče, however, shows also how the choir submits to the political character of the space, or how it places itself in the "political atmosphere" of the location or region. In fact, the southeastern part of the Ljubljana Municipality is a region more closely connected to the partisan past, which is demonstrated today by many monuments from the NLM period and commemorations associated with that time. According to the conductor, when

${ }^{28}$ On the basis of the Ljubljana Partisan Choir repertoire, Ana Hofman (2015a: 55) notes that these songs are "included in the corpus of 'patriotic' songs and presented as Slovenian musical heritage". Perhaps some singers of the Zora Janče Choir also understand them as part of the patriotic expression. 
she conducted the choir in a community on the western border of Ljubljana, she did not even think of including partisan songs in the concert repertoire, as this would anger the local population. During the Second World War, the home guard movement was stronger in the area, and some residents of the area became victims of post-war massacres. That shows how the choir adapts to local and regional socio-political contexts and seeks a "cultivated" consensus and positions within these contexts, which will be shown in more detail in the example of a rehearsed affect described in the following chapter.

\section{COHERENT ATMOSPHERE AND REHEARSED AFFECT}

At sites of gatherings (e.g., protests, dance clubs, sports games) where affective bonds are forged through sound, we often feel bodies cohere in what some describe as "affective alignment with an atmosphere" (Goodman 2010), "entrainment" (ibid.: 172), "synchronicity and solidarity", or "affective attunement" (Garcia 2020). Affective atmospheres theory also assumes that atmospheres are a kind of collective state, a "shared reality" (Böhme 2017: 24) that encompasses different bodies (entities and objects) (Riedel 2019a: 30; Slaby 2014: 43; Vadén and Torvinen 2014: 209-230). Riedel suggests that atmosphere is understood as a feeling that fundamentally transcends a single "body or conscious subject and instead pertains primarily to the overall situation in which a multiplicity of bodies cohere" (2019a: 4) and that the "atmospheric whole cannot be further differentiated into numerable elements or separate meanings" (2019b: 90). The notion of coherence, consistency, and homogeneity has thus taken hold in the theory of affective atmospheres. Singers themselves are also aware of the meaning of such harmony when they speak about the affective relationship with the audience:

It's nice because at these partisan concerts people sing along and they seem to really enjoy it, so it's nice for me too... (J. M., 1 June 2019)

This song pervades me... and this enthusiasm, and after the audience joins in and we all sing together, it's a special feeling of a collective. (M. K., 1 June 2019)

Vadén and Torvinen define affective atmosphere as "a shared perspective space", but point out that "there is still a difference between atmosphere and the emotional state of a person entering the space" (2014: 213). Sara Ahmed (2004: 10) understands it as "thickness in the air", where this thickness is created by "shared feelings". However, she points out that "even when we feel we have the same feeling, we don't necessarily have the same relationship to the feeling" (ibid.). ${ }^{29}$ Thus, one singer describes his affective state, which resembles many other descriptions, but he also experiences "twofold feelings" that are again conditioned by the experience of the political past:

${ }^{29}$ Similarly, emotions and affects can be transferred between bodies with no consequences or without affecting particular bodies, hence affect is left out to excite (Wetherell 2012: 146) or mobilise them. 
When we sang the songs with the brass band, my hair stood up. They are really combative and fill people with energy, belonging. But again, the feelings were twofold. Wouldn't it be nice if left and right [-wing people] could listen to them together with enthusiasm? Well, in the choir we are left-wingers, right-wingers, middle-wingers, and nobodies, and we like to sing them. All of Slovenia should be such a choir. (N. H., 1 June 2019)

Although it is acknowledged that bodies are capable of autonomous sensations that, however, are not necessarily consistent, the affective atmosphere is usually understood as a coherent whole that "cannot be further differentiated into numerable elements or separate meanings" (Riedel 2019b: 90). This makes it more stable and less subject to the influence of possible heterogeneous emotional and affective states of bodies. For example, even if a particular affect does not impact an individual's emotional state or the individual "actively resists the affective grip" (Riedel 2019a: 17), this does not necessarily effect a change in atmosphere. But the atmosphere may disappear if the heterogeneity is too great. In certain cases, coherence, or the affective involvement of bodies in the atmosphere, is also simulated, as explicitly illustrated below using the example of singing rehearsals before choir performance.

Thinking about the affectivity of sound often focuses solely on the temporal and spatial components of musical performance, neglecting a crucial element that happens beforehand: rehearsals. The choir never performs songs without first having conducted many choral rehearsals, which are usually even more intense immediately before the performance and even more focused on the choir sounding "as one singing body". For a high-quality interpretation of the song repertoire (according to musical criteria), it is required that singers perform the text and musical elements of a given song expressively and consistently.

As a singer in the choir in question, I have witnessed the conductor determine the interpretation of a song, partly according to the instructions written in the choir's musical score, partly at her own discretion, and often listening to performances by other choirs and imitating their interpretations. Indeed, singers usually commented on a poor performance on stage by saying "there was a lack of real energy", often due to insecurities in the melodic, harmonic, or textual delivery of the songs. The choir therefore always achieves more security and coherent "energy" when it rehearses the repertoire beforehand to such an extent that it can devote itself to the interpretation required by the song in question and is guided by the conductor's hand movements.

The affectivity and emotionality of a musical performance that is perceived, felt, or embodied by the audience as they sing or listen to the song at the commemoration thus involves a kind of coded affectivity and emotionality that the choir conveys through a predefined and carefully rehearsed interpretation in time and space. A coded interpretation or rehearsed affect leads to both entrainment, synchronicity, or coherence and variance, inconsistency, or incongruity between affect and emotion that is evoked by the interpretation of the song in the listeners and the affects and emotions experienced by the individual 
singers as they sing. Indeed, singers themselves narrate how they control their emotions during the performance: ${ }^{30}$

I think it is inappropriate to over-express emotion in the choir, because it seems to me that we need to act in unison.

We must keep ourselves in check when we sing, sing by the rules.

I guess I would express them [emotions] more than I usually do, but how would it look on stage if each singer expressed emotions in his own way?

In this way, we can also perceive such musical performances as simulated or "insincere" in the transmission of "true" affects and emotions of the singers. Through performance rehearsals - the way of singing, posture, facial expressions, volume, articulation, pronunciation of lyrics, etc. - control becomes another tool for the consciously planned creation of an affective atmosphere.

\section{CONCLUSION}

Looking at commemorations and their instrumentalization of history through the concepts of affect, emotion, and affective atmospheres, we see that their affective power lies in their ability to create resonances between people, the environment, the past, and the present on a personal and interpersonal level. In commemorative practices, various tools are used to mobilize "felt bodies" and fuse them into a coherent affective atmosphere, stimulating a sense of belonging to the community and the ideology it represents. In fact, commemoration is never merely a reminiscence of a historical event, but also an enactment of the past for the purpose of relating it to contemporary political reality. In this context, the establishment of affective atmospheres through ritualization, coded behaviour, and visual and acoustic mediation plays an important role. One of the tools of memory mediation that I particularly emphasise is the sound of partisan songs. Their affective power can be observed in numerous actualizations of the singing of partisan songs in the modern context, mainly re-actualizing their conceptual power in the form of the values they symbolically represent (struggle, rebellion, solidarity, fraternity, etc.). However, the political polarisation rooted in different interpretations of historical events in the period during and after the Second World War in post-socialist Slovenia also reflects the heterogeneity of experiences with music from the NLM period. Although the notion of wholeness, coherence, or homogeneity is widely cited when theorising affective atmospheres, this article shows how this homogeneity in the commemorative performance in Janče is composed of different individual feelings and experiences of the singers of the

\footnotetext{
30 Taken from the anonymous survey of singers of the Zora Janče Choir in 2018 (available at: http:// www.mojaanketa.si/anketa/649782031/). I also noticed that some singers sometimes show their desire for physical expression, for movement while singing, but the prescribed posture in the choir, where the singers stand still and upright, with their bodies, and heads raised and facing the conductor, prevents this.
} 
choir. Their quotations show how sound functions on different spatial and temporal levels and how complex cultural, historical, memorial, personal, and socio-political meanings are involved in their individual experiences. This study's contribution is in highlighting the importance of rehearsed affect in the singing of partisan songs. By singing in rehearsal, the choir encodes the affectivity of the sound and is able to convey feelings different from those experienced by individual singers while singing. The concept of rehearsed affect is transferable to different social contexts in which affect is performed, and the discussion presented here opens directions for further research.

\section{REFERENCES AND SOURCES}

Ahmed, Sara. 2004. The Cultural Politics of Emotion. New York: Routledge.

Anderson, Ben. 2009. "Affective Atmospheres". Emotion, Space and Society 2/2: 77-81. https://doi. org/10.1016/j.emospa.2009.08.005

Atanasovski, Srđan. 2015. "Consequences of the Affective Turn. Exploring Music Practices from Without and Within". Musicology 1/18: 57-74. Available at: http://www.doiserbia.nb.rs/img/doi/14509814/2015/1450-98141518057A.pdf (accessed 20 December 2020). https://doi.org/10.2298/ MUZ1518057A

Böhme, Gernot. 2017. Atmospheric Architectures. The Aesthetics of Felt Spaces. London: Bloomsbury Publishing. https://doi.org/10.5040/9781474258111

Brennan, Teresa. 2004. The Transmission of Affect. Ithaca, New York: Cornell University Press.

Bryan, Dominic. 2016. "Ritual, Identity and Nation. When the Historian Becomes the High Priest of Commemoration". In Remembering 1916 The Easter Rising, the Somme and the Politics of Memory in Ireland. Richard Grayson and Fearghal McGarry, eds. Cambridge: Cambridge University Press, 2442. Available at: https://pureadmin.qub.ac.uk/ws/portalfiles/portal/34838527/Bryan_comemoration_rituals.pdf (accessed 20 December 2020). https://doi.org/10.1017/CBO9781316550403.003

Chebat, Jean-Charles and Richard Michon. 2003. "Impact of Ambient Odors on Mall Shoppers' Emotions, Cognition, and Spending. A Test of Competitive Causal Theories". Journal of Business Research 56/7: 529-539. https://doi.org/10.1016/S0148-2963(01)00247-8

Connerton, Paul. 1989. How Societies Remember. Cambridge, New York: Cambridge University Press. https://doi.org/10.1017/CBO9780511628061

Doss, Erika. 2012. Memorial Mania. Public Feeling in America. Chicago: University of Chicago Press.

Fuchs, Thomas. 2017. "Collective Body Memories". In Embodiment, Enaction, and Culture. Investigating the Constitution of the Shared World. Cristoph Durt, Thomas Fuchs and Christian Tewes, eds. Cambridge: MIT Press, 333-352. https://doi.org/10.7551/mitpress/9780262035552.003.0018

Garcia, Luis-Manuel. 2020. "Feeling the Vibe. Sound, Vibration, and Affective Attunement in Electronic Dance Music Scenes". Ethnomusicology Forum 29/1: 21-39. https://doi.org/10.1080/17411912.20 20.1733434

Goodman, Steve. 2010. Sonic Warfare. Sound, Affect, and the Ecology of Fear. Cambridge, London: MIT Press. https://doi.org/10.7551/mitpress/7999.001.0001

Hacler, Tina. 2013. “Foto. Partizanske pesmi prepevali tudi 'rdeči' slovenski politiki v prvi vrsti”. Available at: https://www.rtvslo.si/mmc-priporoca/foto-partizanske-pesmi-prepevali-tudi-rdeci-slovenski-politiki-v-prvi-vrsti/307685 (accessed 20 December 2020). 
Hedström, Joakim, David Högqvist and Christian Piri. 2015. "Sensory Marketing-Does Music Influence Customers? Effects of Music on Customer Behaviour, Emotions and Perceived Atmosphere Towards a Specific Product Category". Available at: https://www.diva-portal.org/smash/get/diva2:820102/ FULLTEXT02.pdf (accessed 20 December 2020).

Highmore, Ben. 2018. "Mundane Tastes. Ubiquitous Objects and the Historical Sensorium”. In The Persistence of Taste. Art, Museums and Everyday Life After Bourdieu (Culture, Economy and the Social). Malcolm Quinn, David Beech, Michael Lehnert, Carol Wilson and Stephen Wilson, eds. Abingdon: Routledge, 275-287. https://doi.org/10.4324/9781315617299-22

Hofman, Ana. 2015a. Glasba, politika, afekt. Novo življenje partizanskih pesmi v Sloveniji. Ljubljana: Založba ZRC. https://doi.org/10.3986/9789610503477

Hofman, Ana. 2015b. "Introduction to the Co-Edited Issue "Music, Affect and Memory Politics in Post-Yugoslav Space"'. Southeastern Europe 39/2: 145-164. https://doi.org/10.1163/1876333203902001

Hofman, Ana. 2015c. "The Affective Turn in Ethnomusicology". Musicology 1/18: 35-54. Available at: http://www.doiserbia.nb.rs/img/doi/1450-9814/2015/1450-98141518035H.pdf (accessed 20 December 2020). https://doi.org/10.2298/MUZ1518035H

Hofman, Ana. 2020a. "We are the Partisans of Our Time. Antifascism and Post-Yugoslav Singing Memory Activism". Popular Music and Society, 1-18. Available at: https://www.tandfonline.com/doi/full/ 10.1080/03007766.2020.1820782 (accessed 20 December 2020).

Hofman, Ana. 2020b. "New Sincerity and Radical Idealism in Post-Yugoslav Memory Practices". The Media of Memory. Balkan Studies Library 29: 181-193. https://doi.org/10.30965/9783657704477_010

Hofman, Ana and Martin Pogačar. 2017. "Partisan Resistance Today? The Music of the National Liberation Struggle and Social Engagement". Sounds of Attraction. Yugoslav and Post-Yugoslav Popular Music. Rajko Muršič and Miha Kozorog, eds. Ljubljana: Ljubljana University Press, Faculty of Arts, 21-39. Available at: https://e-knjige.ff.uni-lj.si/znanstvena-zalozba/catalog/download/6/28/2991?inline=1 (accessed 20 December 2020).

Hofman Ana, Alenka Bartulović, Mojca Kovačič, Tanja Petrović and Martin Pogačar. 2020. "Afektivni obrat. Koncepti, obeti, omejitve." Glasnik SED 60/1: 56-67.

Kos, Mateja. 2019. "Pomen nacionalnih muzejev pri ohranjanju kolektivnega spomina". Ars et Humanitas 13/1: 234-247. https://doi.org/10.4312/ars.13.1.234-247

Kovačič, Mojca. 2020. "Recording Bracelets a Methodological Tool for Ethnography of Affect". Available at: https://musicaffectpolitics.zrc-sazu.si/mojca-kovacic-recording-bracelets-a-methodological-tool-for-ethnography-of-affect/ (accessed 20 December 2020).

Križnar, Franc. 2014. "Kako misliti glasbo v času druge svetovne vojne na slovenskem (1941-1945)?". Zgodovinski časopis 68/3-4: 388-417.

Luthar, Breda and Oto Luthar. 2003. "Kolonizacija spomina. Politika in tekstualnost domobranskih spomenikov po letu 1991". In Zbornik Janka Pleterskega. Oto Luthar and Jurij Perovšek, eds. Ljubljana: Založba ZRC, ZRC SAZU, 647-662.

Luthar, Oto. 2013. "Forgetting Does (not) Hurt. Historical Revisionism in Post-Socialist Slovenia". Nationalities Papers 41/6: 882-892. https://doi.org/10.1080/00905992.2012.743510

Luthar, Oto. 2017. "Introduction. Red Dragon and the Evil Spirits". In Of Red Dragons and Evil Spirits. Post-Communist Historiography Between Democratization and the New Politics of History. Oto Luthar, ed. New York: Central European University Press, 1-10.

Luthar, Oto and Heidemarie Uhl, eds. 2019. "The Memory of Guilt Revisited. The Slovenian Post-Socialist Remembrance Landscape in Transition”. Zeitgeschichte 46/2. https://doi.org/10.14220/ zsch.2019.46.2.261 
Massumi, Brian. 2002. Parables for the Virtual. Movement, Affect, Sensation. Durham, London: Duke University Press. https://doi.org/10.1215/9780822383574

Mazzarella, William. 2009. "Affect. What Is It Good For?". In Enchantments of Modernity. Sarah Dube, ed. London, New York: Routledge, 291-309. https://doi.org/10.1201/9781003071020-13

Petrović, Tanja. 2016. "Towards an Affective History of Yugoslavia”. Filozofija i društvo 27/3: 504-520. Available at: http://www.doiserbia.nb.rs/img/doi/0353-5738/2016/0353-57381603504P.pdf (accessed 20 December 2020). https://doi.org/10.2298/FID1603504P

Riedel, Friedlind. 2019a. "Atmospheric Relations. Theorising Music and Sound as Atmosphere". In Music as Atmosphere. Friedlind Riedel and Juha Torvinen, eds. London: Routledge, 1-42. https://doi. org/10.4324/9780815358718-1

Riedel, Friedlind. 2019b. "Atmosphere". In Affective Societies. Key Concepts. Jan Slaby and Christian von Scheve, eds. London: Routledge, 85-95. https://doi.org/10.4324/9781351039260-7

Saito, Hiro. 2010. "From Collective Memory to Commemoration". In Handbook of Cultural Sociology. London: Routledge, 629-638.

Schoop, Monika E. 2020. "A Living Memorial for the Edelweißpiraten. Musical Memories of Cologne's Anti-Hitler Youth". Popular Music and Society 44/2: 1-19. https://doi.org/10.1080/03007766.20 20.1820784

Schultz, Corey Kai Nelson. 2016. "Memories in Performance. Commemoration and the Commemorative Experience in Jia Zhangke's 24 City." Film-Philosophy 20/2-3: 265-282. Available at: https:// www.euppublishing.com/doi/10.3366/film.2016.0015 (accessed 20 December 2020). https://doi. org/10.3366/film.2016.0015

Slaby, Jan. 2014. "Emotions and the Extended Mind". Collective Emotions 32: 32-46. Available at: http://janslaby.com/downloads/slaby2014_extendedemotions_oup_final.pdf (accessed 20 December 2020). https://doi.org/10.1093/acprof:oso/9780199659180.003.0003

Smith, Laurajane, Margaret Wetherell and Gary Campbell, eds. 2018. Emotion, Affective Practices, and the Past in the Present. London: Routledge. https://doi.org/10.4324/9781351250962

Spinetti, Federico, Monika E. Schoop and Ana Hofman. 2020. "Introduction to Music and the Politics of Memory. Resounding Antifascism across Borders". Popular Music and Society 44/2: 1-20. Available at: https://www.tandfonline.com/doi/pdf/10.1080/03007766.2020.1820780?needAccess=tr ve (accessed 20 December 2020). https://doi.org/10.1080/03007766.2020.1820780

Sumartojo, Shanti. 2015. "National Identity and Commemorative Space. Connections to the Nation through Time and Site". Landscape Review 15/2: 7-18.

Thompson, Marie and lan Biddle, eds. 2013. Sound, Music, Affect. Theorizing Sonic Experience. London: Bloomsbury Academic. https://doi.org/10.5040/9781501382871

Vadén, Tere and Juha Torvinen. 2014. "Musical Meaning In Between. Ineffability, Atmosphere and Asubjectivity in Musical Experience". Journal of Aesthetics and Phenomenology 1/2: 209-230. https:// doi.org/10.2752/205393214X14083775795032

Wetherell, Margaret. 2012. Affect and Emotion. A New Social Science Understanding. London: Sage Publications. https://doi.org/10.4135/9781446250945

Winter, Jay. 2001. “The Generation of Memory. Reflections on the 'Memory Boom' in Contemporary Historical Studies". Canadian Military History 10/3: 57-64. 


\section{STVARANJE KOHERENTNE ATMOSFERE POMOĆU KOMEMORATIVNIH RITUALA, PJEVANJA PARTIZANSKIH PJESAMA I UVJEŽBANE AFEKTIVNOSTI}

U ovom se članku opisuje komemorativni događaj koji se održava u Janču pokraj Ljubljane te ga se smješta u širi okvir diskursa komemoracija u postsocijalističkom kontekstu u Sloveniji. Načini postizanja ritualizacije prošlosti i sadašnjosti te posredovanja između njih analiziraju se pomoću vizualnih i zvučnih sredstava stvaranja afektivnih atmosfera. U tom je diskursu glazba sredstvo koje objedinjava kako sudionike događaja tako i odnose prošlosti prema sadašnjosti. Članak se bavi reaktualizacijom partizanskih pjesama u kontekstu zborskog pjevanja nakon 1991. godine, a ističu se razlike između reaktualizacije kod aktivističkog i “tradicionalnog” zbora. Politička polarizacija utemeljena na različitim interpretacijama povijesnih događaja iz razdoblja tijekom i nakon Drugog svjetskog rata u postsocijalističkoj Sloveniji odražava se i u heterogenim iskustvima glazbenih izvedbi skladbi iz razdoblja narodnooslobodilačkog pokreta. Ta se tvrdnja ilustrira citatima iz osobnih narativa pjevača zbora Zora Janče sakupljenih nakon komemorativnog događaja. Narativi otkrivaju internu dinamiku koja se povezuje s osobnim doživljajem pjevanja kao i s odjecima kolektivnog pamćenja, prošlosti, povijesti, politike i osobnih iskustava. O heterogenosti doživljaja raspravlja se iz perspektive uloge koju uvježbana ili simulirana afektivnost ima pri stvaranju koherentne afektivne atmosfere.

Ključne riječi: komemoracija, ritualnost, afektivne atmosfere, uvježbana afektivnost, partizanske pjesme 